\title{
Olumsuz Değerlendirilme Korkusu ile Sosyal Medya Reklamlarına Yönelik Tutum İlişkisi
}

\author{
Yelda ÜLKER ${ }^{1}$
}

Öz

İnsanların yaşamlarını devam ettirebilmeleri için çevresiyle iletişim içinde olması önemlidir. Fakat bazen insanlar diğerleriyle iletişim kurarken, kabul görememe veya olumsuz değerlendirilme korkusu yaşamaktadırlar. Bu durum da insanların yalnız kalmayı tercih etmesine sebep olmaktadır. Bu bağlamda olumsuz değerlendirilme korkusuna sahip insanların, diğer insanlarla zaman geçirmek yerine sosyal medyaya yöneldikleri söylenebilir. Böylece kendilerini gizleyebilmekte ama varlıklarını da sürdürebilmektedir. $\mathrm{Bu}$ araştırmanın amacını da olumsuz değerlendirilme korkusuna sahip bireylerin, sosyal medya reklamlarına karşı genel tutumlarını incelemek oluşturmaktadır. Ayrıca araştırmada olumsuz değerlendirilme korkusu ile sosyal medya reklamlarına karşı tutumun alt boyutları olan sosyal medya reklamlarının tercih edilme nedenleri ve sosyal medya reklamlarına yönelik tüketici kanaati de irdelenmektedir. Bunlara ek olarak araştırmada katılımcıların demografik özellikleri ile olumsuz değerlendirilme korkuları arasında anlamlı bir farkın olup olmadığı da incelenmektedir. Araştırmada elde edilen verilere göre katılımcıların olumsuz değerlendirilme korkusu ile sosyal medya reklamlarına yönelik tutumları arasında herhangi bir ilişki yokken, olumsuz değerlendirilme korkusuyla katılımcıların demografik özelliklerinden bazıları arasında fark bulunmaktadır.

Anabtar Kelimeler: Olumsuz Değerlendirilme Korkusu, Sosyal Medya, Sosyal Medya Reklamları

\section{Relationship between Fear of Negative Evaluation and Attitude towards Social Media} Ads

\section{Abstract}

It is important for people to be in contact with their environment in order to continue their lives. However, sometimes when people communicate with others, they fear being disapproved or negatively evaluated. This situation causes people to prefer to be alone. In this context, it can be said that people who fear being evaluated negatively tent to social media instead of spending time with other people. Thus, they can hide themselves but also continue their existence. The purpose of this study is to examine the general attitudes of individuals who fear negative evaluation towards social media advertisements. In addition, the fear of negative evaluation and the reasons for preferring social media ads, which are sub-dimensions of the attitude towards social media ads, and consumer opinion towards social media advertisements are also examined. In addition to these, is also examined whether there is a significant difference between the demographic characteristics of the participants and their fear of negative evaluation. According to the findings, while there is no relationship between the fear of negative evaluation and their attitudes towards social media advertisements, there is a difference between the fear of being evaluated negatively and some of the demographic characteristics of the participants.

Key Words: Fear of Negative Evaluation, Social Media, Social Media Ads

Atıf İçin / Please Cite As:

Ülker, Y. (2021). Olumsuz değerlendirilme korkusu ile sosyal medya reklamlarına yönelik tutum ilişkisi. Manas Sosyal Arastermalar Dergisi, 10(2), 1300-1313. 


\section{Giriş}

Bireyler yaşamlarını sürdürebilmek için diğer insanlarla iletişim kurma ihtiyacı hissetmektedir. Bu ihtiyacı karşılarken bireyler, iletişim kurdukları kişilerde nasıl bir izlenim bıraktıklarına ve nasıl değerlendirildiklerine önem vermektedirler. Fakat bazen bireyler, iletişim kurdukları kişilerde olumsuz izlenim bırakmaktan yoğun bir şekilde korkmaktadır. Bu durumda bazen kişilerde huzursuzluk ve kaçınma gibi sosyal kaygıların oluşmasına sebep olmaktadır (Çam vd., 2010, s. 133). Bu bağlamda sosyal kaygı kavramı, bireylerin başarılı olamayacaklarına, diğer insanların kendilerini olumsuz değerlendireceklerine veya reddedeceklerine olan inançları olarak tanımlanmaktadır. Sosyal kaygı taşıyan kişilerin, yeteneklerine ve performanslarına yönelik şüpheleri bulunmakta olup; olumsuz değerlendirileceklerine olan inançları doğrultusunda topluluk önünde konuşmama, göz kontağı kuramama ve grup çalışmalarına katılmama gibi davranışlar sergilemektedirler (Rapee ve Heimberg, 1997, s. 741-742). Bu sebeple olumsuz değerlendirilme korkusunun sosyal kaygının anlaşılmasında temel bir özellik olduğu söylenebilir (Rapee ve Heimberg, 1997; Carleton vd., 2007, s. 132). Diğer bir deyişle bireyler, diğer insanlar tarafindan olumsuz değerlendirilme kaygısı duymalarından dolayı sosyal ortamlara girmekten kaçınmaktadırlar. Bu bağlamda olumsuz değerlendirilme korkusu, bireylerin değerlendirilmekten kaçması, aşağılanacağıyla, rezil olacağıyla ilgili aşırı ve sürekli endişe duyması olarak tanımlanmaktadır (Weeks vd., 2008, s. 45). Olumsuz değerlendirilme korkusu kavramını ilk kez kullanan Watson ve Friend'de (1969, s. 449), bireylerin değerlendirilmekten kaçması, endişe duyması, değerlendirilebileceği ortamlara girmeyerek olası bir değerlendirmeyi engellemesi ve olumsuz önyargilardan kaynaklı olarak diğer insanların kendilerini olumsuz değerlendireceğine inanması olarak tanımlamaktadır. Başkaları tarafından olumlu değerlendirmeye önem veren bireyler, başkalarının karşısında yeteneklerini sergilemeleri gerektiği zamanlarda, diğer insanların kendilerinden yüksek ve başarılı bir performans beklediklerine inanmaktadırlar. Bu durumda bireylerin kendi performanslarından kussku duymalarına ve korkmalarına sebep olmaktadır. Bununla birlikte olumsuz değerlendirilmekten korkan bireyler, kötü performans sergiledikleri takdirde diğer insanlar tarafından dışlanacaklarına da inanmaktadırlar (Rapee ve Heimberg, 1997, s. 748).

Yukarıdaki bilgiler ışığında bireylerin, başkaları tarafından olumsuz algılanmamak, değerlendirilmemek için bazı davranışlar sergiledikleri söylenebilir. Bu bağlamda Akyüz ve arkadaşlarının (2017, s. 261-274) "olumsuz değerlendirilme korkusu ile ani kompulsif satın alma davranışı ilişkisinde yatay bireysellik ve/veya normatif uyumluluğun olası etkilerinin incelenmesi” adlı çalışmalarında bireylerin olumsuz değerlendirilme korkusu ile ani satın alma davranışı göstermesi arasında bir ilişkinin olduğu tespit edilmiştir. Ayrıca çalışmada, katılımcıların demografik yapılarıyla ilgili bir farklılığa da rastlamamıştır. Fakat Carleton, Collimore ve Asmundson'un (2007, s. 138) yapmış olduğu araştırmada katılımcıların olumsuz değerlendirilme korkusu ile cinsiyetleri arasında farklilikların olduğu görülmektedir. Carleton ve arkadaşlarının yapmış oldukları çalışmaya benzer bir araştırma yapan Habke ve arkadaşları (1997) ile Turk ve arkadaşları (1998) da aynı sonuca ulaşmıştır. Bahsedilen bu araştırmaların sonucunda olumsuz değerlendirilme korkusu ile katılımcıların cinsiyetleri arasında farklılıkların olduğu görülmektedir. Fakat yurtdışında yapılan araştırmaların aksine, Türkiye'deki çalışmaların sonucunda olumsuz değerlendirilme korkusu ile cinsiyet arasında farklılıklar görülmemektedir (Erkan vd., 2002; Koydemir ve Demir, 2007; Çam vd., 2010; Karabulut ve Bahadır, 2013). Türkiye'de yapılan araştırmalarda katılımcıların cinsiyetleriyle olumsuz değerlendirilme korkuları arasında bir farklılık bulunmasa da, Köse ve arkadaşlarının (2016, s. 358) yapmış olduğu araştırmaya göre, bireylerin olumsuz değerlendirilme korkusu ile vücut alg1 düzeyleri arasında bir ilişki bulunmaktadır. Fakat Köse'de araştırmasında, olumsuz değerlendirilme korkusu ile cinsiyetleri arasında fark belirlememiştir. Bununla birlikte katılımcıların tanımlayıcı özellikleri ile olumsuz değerlendirilme korkusu arasında farklılıkların olduğu araştırmalar da bulunmaktadır. Örneğin Irmak (2015, s. 59-70) “ortaöğretim öğrencilerinin olumsuz değerlendirilme korkusu ve öğrenmeye ilişkin tutumlarının incelenmesi” adlı çalışmasında, elde ettiği veriler doğrultusunda katılımcıların tanımlayıcı özellikleri ile olumsuz değerlendirilme korkusu arasında farkllıklar belirlemiştir. Çalışmaya göre, katılımcıların liselerinin türü (meslek/Anadolu), kaçıncı sınıf olduklarına ve aile üyelerinin eğitim düzeyleri ile olumsuz değerlendirilme korkusu arasında anlamlı farklılıklar bulunmaktadır. Bununla birlikte olumsuz değerlendirilme ve reddedilme korkusu bireylerin davranışına da yansımaktadır. Örneğin Ömür ve arkadaşlarının (2014, s. 141-146) öğretmen adaylarına yapmış olduğu araştırmaya göre, olumsuz değerlendirilme korkusu yüksek olan katılımcılar, akademik sahtekarlığa meyilli olabilmektedir. Diğer bir deyişle olumsuz değerlendirilme korkusu yaşayan katılımcılar, raporlarında, araştırmalarında, ödev ve projelerinde sahtekarlık eğilimleri gösterebilmektedir. 
Günümüzde bireyler, duygu ve düşüncelerini sosyal medya aracıllğgyla diğer insanlara ulaştırmaktadır. Diğer bir deyişle sosyal medya üzerinden, bireyler yeni fikirler üretip, tartışabilmekte, kendi istekleri doğrultusunda kişisel bilgilerini, fotoğraflarını ve videolarını paylaşabilmektedir. Böylece bireyler hem üreten hem de tüketen olarak, sosyal medyadaki yerini almaktadır (Koçak, 2012, s. 7). Bu bağlamda bireyler, kendi seçtikleri ve kolayca kontrol edilebildikleri ortamlarda, konforlu ve güvenli bir şekilde diğer insanlarla tanışıp, çeşitli aktivitelere katılmaktadır (Madell ve Muncer, 2007, s. 139). Amichai-Hamburger ve Barak'ın (2009, s. 34-76) çalışmasına göre de, bireyler diğer insanlarla ilişki kurmak ve sosyal ihtiyaçlarını karşılamak için sosyal medyadan faydalanmaktadır (s.34-76). Çünkü bazı insanlar, diğer insanlarla yüz yüze iletişim kurmak istememekte, sanal ortamda kurulan iletişimi daha az tehdit edici bulmaktadır (Caplan, 2002, s. 563). Bu konuda Yen ve arkadaşlarının (2012, s. 7) yapmış olduğu çalışmaya göre de, bazı bireyler çevirim içi etkileşim içindeyken, yüz yüze iletişime oranla daha az kaygı ve stres duymaktadır. Caplan'n (2007) yapmış olduğu araştırmaya göre ise, bireyin yüz yüze iletişim kurmaktan ziyade sosyal medyada var olmak istemesinin temel nedenlerinden biri bireyin kendisini gizleyebilmesidir. Diğer bir deyişle bireyler sosyal medya sayesinde mahremiyetlerini koruyabilmekte ve diğer insanlarla iletişim kurarken daha az risk taşımaktadır. Bu sebeple özellikle olumsuz değerlendirilmekten korkan bireyler, kendilerini sosyal medyada daha rahat hissedip, daha kolay ifade edebilmektedir. Örneğin Zorbaz’ın (2013) lise öğrencileriyle yapmış olduğu araştırmaya göre, olumsuz değerlendirilme korkusu yüksek olan katıllımcıların, aşırı internet kullandığ1 belirlenmiştir. Araştırmaya göre, bunun sebebi internet ortamında bireylerin değerlendirilmediklerine inanmalarından, kendilerini özgür hissetmelerinden ve kimliklerini gizleyebilmesinden kaynaklanmaktadır. Bu bağlamda elde edilen veriler sonucunda olumsuz değerlendirilme korkusuna sahip katılımcılarının daha fazla sosyal medyada yer aldığı söylenebilir (s.76). Çetin ve Ceyhan'ın (2014) 2729 öğrenciyle gerçekleştirdikleri çalışmaya göre katıllımciların büyük bir kısm1 sosyal medyada, diğer insanlarla daha rahat ve kolay iletişim kurmak için başka biriymiş gibi davranmaktadır (22). Çakmak'ın (2014) yapmış olduğu araştırmaya göre de, sosyal medya kullanımı ile iletişim kaygısı arasında anlamlı bir ilişki bulunmaktadır. Ayrıca katılımcılarını Aksaray, Ankara, İstanbul ve Selçuk Üniversite öğrencilerinin oluşturduğu araştırmada, bireylerdeki iletişin kaygısıyla sosyal medya kullanım sıklıkları ile sosyal medya eylemlerini gerçekleştirme sıklıkları arasında anlamlı bir ilişkinin var olduğu saptanmıştır. Savc1 ve Aysan'da (2018) “\#Kişilerarası Yetkinlik, Yalnızlık, Olumsuz Değerlendirilme Korkusu, Ödül ve Cezanın Sosyal Medya Bağımlılığını Yordama ve Sosyal Medya Kullanan-Kullanmayan Ergenleri Doğru Sinıflandırma Düzeyi” adlı çalışmalarında olumsuz değerlendirilme korkusunun bireylerin sosyal medya bağımlılı̆̆ını etkilediğini tespit etmişlerdir. Araştırmada sosyal medya bağımlliğı ile olumsuz değerlendirilme korkusu arasında anlamlı bir ilişki bulunsa da, bireyin sosyal medya kullanıcısı olması ile ilgili bir ilişki bulunmamaktadır. Diğer bir deyişle sosyal medya kullanıcısı olup/olmamakla, olumsuz değerlendirilme korkusuna sahip olmak arasında bir anlam yoktur (464-465). Olumsuz değerlendirilme korkusuna sahip bireylerin gerçek kimliklerini ifşsa etmek zorunda olmadıkları, saklanabildikleri ve daha az riskli buldukları için sosyal medyaya yöneldikleri söylenebilir (Huan vd., 2014).

Hayatın her alanına girmiş olan sosyal medya, teknolojinin gelişimiyle birlikte; hızlı, kolay ve etkin bir şekilde insanlara ulaşabilmektedir. Bu özelliklerinden dolayı sosyal medya, marka yöneticilerinin de dikkatini çekmektedir (Değer, 2018, s. 170). Geniş kitlelere hızlı, kolay ve etkin bir şekilde ulaşılabilmesinden dolayı markalar, iletişim çalışmalarını sosyal medya üzerinden gerçekleştirmektedir. Böylece markalar hedef kitlelerine daha rahat ve kolay ulaşmanın yanı sıra onlardan da geri dönüşüm alabilmektedir. Bu bilgiler ışığında tüketicilerin duygularını, kişiliklerini ve onları tanımlayan diğer özelliklerini markalar tarafindan anlamak önemlidir. Bu bağlamda olumsuz değerlendirilme korkusuna sahip bireylerin sosyal medyayı sık sı kullandıkları bilinmektedir. Bu sebeple çalışmada olumsuz değerlendirilme korkusuna sahip bireylerin, sosyal medya reklamlarına olan tutumları irdelenmiştir. Böylece olumsuz değerlendirilme korkusu yaşayan ve sosyal medya kullanan tüketicilerin, sosyal medyada yayınlanan reklamlara olan tutumları incelenebilmektedir. Ayrıca tüketicilerin internet kullanımları ile sosyal medyaya olan tutumları da irdelenen konular arasindadır.

\section{Yöntem}

Nicel araştırma yaklaşımına dayalı olarak belirlenen çalışmada, olumsuz değerlendirilme korkusuna sahip bireylerin, sosyal medya reklamlarına karşı genel tutumlarını incelemek oluşturmaktadır. Ayrıca araştırmada olumsuz değerlendirilme korkusu ile sosyal medya reklamlarına karşı tutumun alt boyutları olan sosyal medya reklamlarının tercih edilme nedenleri ve sosyal medya reklamlarına yönelik tüketici kanaati de irdelenmektedir. Bunlara ek olarak araştırmada katılımcıların demografik özellikleri ile olumsuz 
değerlendirilme korkuları arasında anlamlı bir farkın olup olmadığı da incelenmektedir. Bu amaçlar doğrultusunda araştırmada, Aktan'in (2018), Rapee ve Heimberg'in (1997), Woods ve Scott'un (2006), Huan vd.'nin (2014), Savc1 ve Aysan'ın (2018), Çetin vd.'nin (2010) ve Mir'in (2014) çalışmalarından yararlanılarak aşağıda yer alan hipotezler oluşturulmuştur:

H1: Olumsuz değerlendirilme korkusu ile katılımcıların demografik özellikleri arasında anlamlı bir fark vardir.

H1a: Olumsuz değerlendirilme korkusu ile katılımcıların cinsiyetleri arasında fark vardır.

H1b: Olumsuz değerlendirilme korkusu ile katılımcıların yaşları arasında fark vardır.

H1c: Olumsuz değerlendirilme korkusu ile katılımcıların eğitim seviyeleri arasında fark vardır.

H1d: Olumsuz değerlendirilme korkusu ile katılımcıların medeni durumları arasında fark vardır.

H1e: Olumsuz değerlendirilme korkusu ile katılımcıların çalışma durumları arasında fark vardır.

H1f: Olumsuz değerlendirilme korkusu ile katılımcıların aylık gelir durumları arasında fark vardır.

H1g: Olumsuz değerlendirilme korkusu ile katılımcıların günlük internette geçirilen saatleri arasında fark vardir.

H2: Olumsuz değerlendirilme korkusu ile sosyal medya reklamlarına karşı genel tutum arasında anlamlı bir ilişki vardır.

H2a: Olumsuz değerlendirilme korkusu ile sosyal medya reklamlarına karşı tutumun alt boyutu olan sosyal medya reklamlarının tercih edilme nedenleri arasında anlamlı bir ilişki vardır.

H2b: Olumsuz değerlendirilme korkusu ile sosyal medya reklamlarına karşı tutumun alt boyutu olan sosyal medya reklamlarına yönelik tüketici kanaati arasında anlamlı bir ilişki vardır.

\section{Evren - Örneklem}

Olumsuz değerlendirilme korkusuna sahip bireyler, topluluk içinde yanlış yapmaktan, olumsuz bir izlenim oluşturmaktan çekinmektedir. Bu durum da bireylerin sosyal ortamlarda rahat davranmalarına engel olmaktadır. Bu psikolojik sıkıntılardan kurtulmak için bireyleri kendilerini gizleyebildikleri, daha rahat iletişim kurdukları sosyal medyaya yönlendirebilmektedir. Bu bağlamda araştırmanın amacı olumsuz değerlendirilme korkusu yaşayan bireylerin sosyal medya reklamlarına olan anlamlı bir ilişkinin olup olmadığının irdelenmesidir. Araştırmanın ana kütlesini ise sosyal medya kullanımı yüksek olan üniversite öğrencileri oluşturmaktadır (Vural ve Bat, 2010). Bilgi ve verilerin elde edilmesi kolay toplanabilmesi için kolayda örnekleme yöntemine (Kurtuluş, 2010, s. 63) başvurulan araştırmanın katılımcılarını bu sebeple Marmara Üniversitesi öğrencileri oluşturmaktadır. Ayrıca problem çözümüne yönelik araştırmalarda örnek hacmi 300 ile 500 kişi arasında tutulduğu (Naresh ve Birks, 2000, s. 351) için çalışmada, 308 öğrenciye yüz yüze anket uygulanmıştır. Araştırma, zaman ve maliyet kısıtlarından dolayı sadece Marmara Üniversitesi ile sınırlı kalmıştır. Bu nedenle araştırma sonuçlarının Türkiye'ye genellemesi gibi bir durum söz konusu değildir. 


\section{ÜLKER}

Olumsuz Değerlendirilme Korkusu ile Sosyal Medya Reklamlarına Yönelik Tutum İlişkisi

Tablo 1. Katılimcolara İliskin Tanmlayıcı Özellikler (n=308)

\begin{tabular}{|c|c|c|c|}
\hline & Gruplar & Frekans(n) & Yüzde (\%) \\
\hline \multirow{2}{*}{ Cinsiyet } & Erkek & 153 & 49,7 \\
\hline & Kadin & 155 & 50,3 \\
\hline \multirow{3}{*}{ Yaş } & 20 ve Alt1 & 70 & 22,7 \\
\hline & $21-30$ & 207 & 67,2 \\
\hline & 30 ve Üzeri & 31 & 10,1 \\
\hline \multirow{3}{*}{ Yükseköğretim Seviyesi } & Ön lisans & 26 & 8,4 \\
\hline & Lisans & 171 & 55,5 \\
\hline & Lisansüstü & 111 & 36,0 \\
\hline \multirow{2}{*}{ Medeni Durum } & Evli & 29 & 9,4 \\
\hline & Bekâr & 279 & 90,6 \\
\hline \multirow{2}{*}{ Çalışma Durumu } & Evet & 115 & 37,3 \\
\hline & Hayır & 193 & 62,7 \\
\hline \multirow{4}{*}{ Aylık Gelir } & 1000 ve Alt1 & 123 & 39,9 \\
\hline & $1001-2000$ & 60 & 19,5 \\
\hline & 2001-3000 & 54 & 17,5 \\
\hline & 3000 ve Üzeri & 71 & 23,1 \\
\hline \multirow{4}{*}{$\begin{array}{l}\text { Günlük İnternette Geçirilen } \\
\text { Saat }\end{array}$} & 2 Saatten Az & 44 & 14,3 \\
\hline & 3-5 Saat & 174 & 56,5 \\
\hline & 6-8 Saat & 65 & 21,1 \\
\hline & 8 Saat Üzeri & 25 & 8,1 \\
\hline
\end{tabular}

Tablo 1'de katılımciların cinsiyete göre 153'ü (\%49,7) erkek, 155'i (\%50,3) kadın olarak dağıldığı görülmektedir. Ayrıca katılımcıların 70'inin (\%22,7) 20 ve altı yaş aralığında, 207'sinin (\%67,2) 21-30 aralıkta, 31'i ise (\%10,1) 30 yaş ve üzeri olmakla birlikte, 171'i (\%55,5) lisans öğrenimi gördüğü, 279'luk $(\% 90,6)$ bir kısmının bekar olduğu ve bunlardan 193'ünün $(\% 62,7)$ çalıșmadığı belirlenmiștir. Bu bilgilerin yanı sıra katılımcıların 123 'ü $(\% 39,9) 1000$ TL ve altı gelire sahipken, $174^{\prime} l u ̈ k ~(\% 56,5)$ bir kesim internette 3-5 saat arasında zaman geçirmektedir.

\section{Veri Toplama Araçları}

Kișisel Bilgi Formu: Katılımcılara ait cinsiyet, yaş, eğitim seviyesi, çalışma durumu, ayllk geliri, günlük internette geçirilen saatin aralı̆̆na ilişkin bilgilere ulaşılmasına yönelik sorular araştırmacılar tarafindan oluşturulmuştur.

Veri Toplama Araçlar: iki bölümden oluşmaktadır. Anketin ilk bölümünde katılımcıların olumsuz değerlendirilme korkularını ölçmeye yönelik sorular bulunmaktadır. Bu bağlamda Çetin ve arkadaşlarının (2010) "Olumsuz değerlendirilme korkusu ölgeği kısa formu'nun uyarlamasi: gecerlike ve gïvenirlik çallsması" adlı ölçekten yararlanılmıştır. Çetin ve arkadaşları ölçeği oluştururken, Leary (1983) tarafindan geliştirilen "The brief fear of negative evaluation scale (BFNE)" adlı çalısmayı Türkçeye uyarlayıp, yararlanmıştır. İkinci bölümde ise katılımcıların sosyal medya reklamlarına olan tutumlarını ölçek amaçlanmıştır. Bu amaç doğrultusunda Mir'in (2014), "Effects of pre-purchase search motivation on user attitudes toward online social network advertising: a case of university students" adlı çalışmasından yararlanılmıştır. Her iki ölçeğin ifadelerinin ilgili kategorilerinin uygunluğu 5 'li skala üzerinden değerlendirilmiştir.

\section{Verilerin Analizi}

Araştırmadan elde edilen bulgular "Statistical Package for Social Sciences for Windows 22.0" adlı programı kullanılarak analiz yapılmıştır. Elde edilen bulguların değerlendirilmesinde tanımlayıcı istatistiksel yöntemleri olarak "sayı", "yüzde", "ortalama" ve "standart sapma" kullanılmıştır. Araştırmada iki bağımsız grup arasında verilerin karşılaştırılması için "t-testi" ve ikiden fazla bağımsız grup arasındaki niceliksel sürekli verilerin karşılaştırılması için ise "One Way Anova" testine başvurulmuştur. Ayrıca araştırmada Anova testi sonrasında farkllıkları belirlemek üzere tamamlayıcı post-hoc analizi olarak "Scheffe" adlı test yapılmıştır. Bunlara ek olarak çalışmada sürekli değişkenleri arasında "Pearson Korelasyon" adlı analiz kullanılmıştır. Araştırmada kullanılan "olumsuz değerlendirilme korkusu" adlı ölçeğin güvenirliği Cronbach's Alpha $=0,883$ olarak, yüksek bulunmuştur. Ayrıca araştırmada "sosyal medya reklamlarına olan tutumu" belirlemek için kullanılan diğer ölçeğin güvenirliği Cronbach's Alpha=0,923 olarak yüksek çıkmıştır. 


\section{Bulgular}

Bu bölümde araştırmadan elde edilen veriler ve onların yorumlanması yer almaktadır.

Tablo 2. Katılımclarm Olumsuz Değerlendirilme Korkusu ve Sosyal Medya Reklamlarna Karşı Tutumlar İle Ilgili Ifadelere Verdiğ Cevaplarn Dağzllmian

\begin{tabular}{|c|c|c|c|c|c|c|c|c|c|c|c|c|}
\hline & \multicolumn{2}{|c|}{ 综 } & \multicolumn{2}{|c|}{ 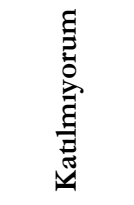 } & \multicolumn{2}{|c|}{ 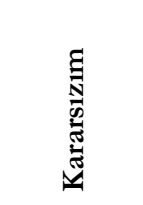 } & \multicolumn{2}{|c|}{ 胥 } & \multicolumn{2}{|c|}{ 焉 } & \multirow[b]{2}{*}{ Ort } & \multirow[b]{2}{*}{ Ss } \\
\hline & $\mathrm{f}$ & $\%$ & $\mathrm{f}$ & $\%$ & $\mathrm{f}$ & $\%$ & f & $\%$ & $f$ & $\%$ & & \\
\hline $\begin{array}{l}\text { Önemli olmadığını bilsem de başkalarının hakkımda } \\
\text { ne düşündüğü beni endişelendirir }\end{array}$ & 46 & 14,9 & 81 & 26,3 & 91 & 29,5 & 59 & 19,2 & 31 & 10,1 & 2,830 & 1,196 \\
\hline $\begin{array}{l}\text { Insanların benimle ilgili olumsuz } \\
\text { olduğunu bilsem bile bunu umursamam }\end{array}$ & 28 & 9,1 & 77 & 25,0 & 130 & 42,2 & 53 & 17,2 & 20 & 6,5 & 2,870 & 1,016 \\
\hline $\begin{array}{l}\text { Çoğu zaman insanların benim kusurlarımı fark } \\
\text { edeceklerinden korkarım }\end{array}$ & 55 & 17,9 & 93 & 30,2 & 85 & 27,6 & 61 & 19,8 & 14 & 4,5 & 2,630 & 1,124 \\
\hline Başkalarının beni onaylamayacağından korkarım & 55 & 17,9 & 125 & 40,6 & 51 & 16,6 & 68 & 22,1 & 9 & 2,9 & 520 & 1,108 \\
\hline $\begin{array}{l}\text { Diğer insanların bende bir kusur bulacaklarından } \\
\text { korkarım }\end{array}$ & 56 & 18,2 & 110 & 35,7 & 80 & 26,0 & 44 & 14,3 & 18 & 5,8 & 2,540 & 1,119 \\
\hline $\begin{array}{l}\begin{array}{l}\text { Diğer insanların hakkımdaki düşünceleri beni } \\
\text { rahatsız etmez }\end{array} \\
\end{array}$ & 20 & 6,5 & 94 & 30,5 & 111 & 36,0 & 52 & 16,9 & 31 & 10,1 & 2,940 & 1,066 \\
\hline $\begin{array}{l}\text { Birileriyle konuşurken benim hakkımda ne } \\
\text { düşünecekleri ile ilgili endişelenirim }\end{array}$ & 47 & 15,3 & 102 & 33,1 & 90 & 29,2 & 56 & 18,2 & 13 & 4,2 & 2,630 & 1,077 \\
\hline $\begin{array}{l}\text { Genellikle başkaları üzerinde nasıl bir izlenim } \\
\text { bıraktı̆̆ımla ilgili olarak endişe duyarım }\end{array}$ & 34 & 11,0 & 85 & 27,6 & 82 & 26,6 & 88 & 28,6 & 19 & 6,2 & 2,910 & 1,116 \\
\hline $\begin{array}{l}\text { Eğer birisi benimle ilgili bir değerlendirmede } \\
\text { bulunursa, bu beni çok fazla etkilemez }\end{array}$ & 27 & 8,8 & 93 & 30,2 & 117 & 38,0 & 55 & 17,9 & 16 & 5,2 & 2,810 & 1,002 \\
\hline $\begin{array}{l}\text { Bazen diğer insanların hakkımda ne düşündükleri ile } \\
\text { ilgili olarak fazla endişelendiğimi düşünüyorum }\end{array}$ & 53 & 17,2 & 98 & 31,8 & 69 & 22,4 & 69 & 22,4 & 19 & 6,2 & 2,690 & 1,176 \\
\hline $\begin{array}{l}\text { Çoğunlukla yanlış bir şey yapacağım ya da } \\
\text { söyleyeceğim diye endişelenirim }\end{array}$ & 34 & 11,0 & 98 & 31,8 & 63 & 20,5 & 82 & 26,6 & 31 & 10,1 & 2,930 & 1,195 \\
\hline $\begin{array}{l}\text { Satın alma kararlarımı destekleyecek önerileri } \\
\text { bulmak için sosyal medya reklamlarını kullanıyorum }\end{array}$ & 76 & 24,7 & 72 & 23,4 & 78 & 25,3 & 70 & 22,7 & 12 & 3,9 & 2,580 & 1,196 \\
\hline $\begin{array}{l}\text { Ürünler ve hizmetler hakkında ayrıntılı bilgi almak } \\
\text { için sosyal medya reklamlarını kullanıyorum }\end{array}$ & 72 & 23,4 & 80 & 26,0 & 72 & 23,4 & 69 & 22,4 & 15 & 4,9 & 2,590 & 1,206 \\
\hline $\begin{array}{l}\text { Bilgi alıp, doğru satın alma kararları vermek için } \\
\text { sosyal medya reklamlarını kullanıyorum }\end{array}$ & 63 & 20,5 & 71 & 23,1 & 86 & 27,9 & 75 & 24,4 & 13 & 4,2 & 2,690 & 1,170 \\
\hline $\begin{array}{l}\text { Bir satın alma kararında yer alan sorunları nasıl } \\
\text { çözeceğinizi öğrenmek için sosyal medya } \\
\text { reklamlarını kullanıyorum }\end{array}$ & 76 & 24,7 & 92 & 29,9 & 91 & 29,5 & 49 & 15,9 & 0 & 0,0 & 2,370 & 1,023 \\
\hline $\begin{array}{l}\text { Alacağım riski en aza indirmek için sosyal medya } \\
\text { reklamların kullanıyorum }\end{array}$ & 81 & 26,3 & 83 & 26,9 & 92 & 29,9 & 43 & 14,0 & 9 & 2,9 & 2,400 & 1,107 \\
\hline $\begin{array}{l}\text { Sosyal medya reklamcilı̆̆ının çok önemli olduğunu } \\
\text { düşünüyorum }\end{array}$ & 37 & 12,0 & 25 & 8,1 & 83 & 26,9 & 100 & 32,5 & 63 & 20,5 & 3,410 & 1,241 \\
\hline $\begin{array}{l}\text { Sosyal medya reklamcilğ̆ına karşı genel tutumum } \\
\text { oldukça olumludur }\end{array}$ & 58 & 18,8 & 69 & 22,4 & 98 & 31,8 & 63 & 20,5 & 20 & 6,5 & 2,730 & 1,173 \\
\hline $\begin{array}{l}\begin{array}{l}\text { Sosyal medya reklamcilı̆̆ hakkında genel fikrim } \\
\text { olumlu }\end{array} \\
\end{array}$ & 57 & 18,5 & 63 & 20,5 & 88 & 28,6 & 78 & 25,3 & 22 & 7,1 & 2,820 & 1,207 \\
\hline $\begin{array}{lccc}\text { Sosyal medyada } & \text { gösterilen } & \text { ürünlerin } & \text { afiş } \\
\text { reklamların severim } & & & \\
\end{array}$ & 75 & 24,4 & 42 & 13,6 & 88 & 28,6 & 84 & 27,3 & 19 & 6,2 & 2,770 & 1,258 \\
\hline $\begin{array}{l}\text { Sik sik sosyal medyadaki banner reklamlarını } \\
\text { tuklarım }\end{array}$ & 132 & 42,9 & 94 & 30,5 & 57 & 18,5 & 23 & 7,5 & 2 & 0,6 & 1,930 & 0,984 \\
\hline $\begin{array}{l}\text { Sosyal medya profilimde gösterilen reklamları s1k } \\
\text { s1k tıklıyorum }\end{array}$ & 132 & 42,9 & 95 & 30,8 & 52 & 16,9 & 24 & 7,8 & 5 & 1,6 & 1,940 & 1,027 \\
\hline
\end{tabular}




\section{ÜLKER}

Araştırmaya katılan katılımcıların Olumsuz Değerlendirilme Korkusu ve Sosyal Medya Reklamlarına Karşı Tutum ilgili ifadelere verdiği cevaplar incelendiğinde;

"Önemli olmadiğm bilsem de başkalarmm hakkermda ne düşündügü beni endişelendirir" ifadesine katılımc1ların, \%14,9'u ( $\mathrm{n}=46)$ hiç katılmiyorum, \%26,3'ü ( $\mathrm{n}=81$ ) katlmiyorum, \%29,5'i (n=91) kararsızım, \%19,2'si $(\mathrm{n}=59)$ katilıyorum ve \%10,1'i $(\mathrm{n}=31)$ ise tamamen katllyorum yanıtını vermiştir. Katılımcıların " önemli olmadığını bilsem de başkalarının hakkımda ne düşündüğü beni endişelendirir” ifadesine orta $(\bar{x}=2,830)$ düzeyde katıldıkları belirlenmiştir.

"İnsanlarn benimle ilgili olumsuz izlenimleri olduğunu bilsem bile bunu umursamam" ifadesine kat1limciların, $\% 9,1^{\prime} \mathrm{i}(\mathrm{n}=28)$ hiç katılmıyorum, \%25,0'i $(\mathrm{n}=77)$ katılmıyorum, \%42,2'si $(\mathrm{n}=130)$ kararsızım, \%17,2'si $(\mathrm{n}=53)$ katıllyorum, \%6,5' $\mathrm{i}(\mathrm{n}=20)$ tamamen katıllyorum yanıtını vermiştir. katılımcıların " insanların benimle ilgili olumsuz izlenimleri olduğunu bilsem bile bunu umursamam" ifadesine orta $(\bar{x}=2,870)$ düzeyde katıldıkları belirlenmiştir.

"Coğu zaman insanlarn benim kusurlarm fark edeceklerinden korkarm" ifadesine katılimciların, \%17,9'u ( $\mathrm{n}=55)$ hiç katılmiyorum, \%30,2'si (n=93) katılmiyorum, \%27,6's1 ( $\mathrm{n}=85)$ kararsızım, \%19,8'i (n=61) katılıyorum, \%4,5'i ( $\mathrm{n}=14)$ tamamen katıllyorum yanıtını vermiştir. Katılımcıların " çoğu zaman insanların benim kusurlarımı fark edeceklerinden korkarım" ifadesine orta $(\overline{\mathrm{x}}=2,630)$ düzeyde katıldıkları belirlenmiştir.

"Başkalarmm beni onaylamayacağından korkarmm" ifadesine katılımcıların, $\% 17,9$ 'u $(\mathrm{n}=55)$ hiç katılmıyorum, $\% 40,6$ 's1 (n=125) katilmiyorum, \%16,6's1 ( $\mathrm{n}=51)$ kararsizım, \%22,1'i (n=68) kat1lyorum, \%2,9'u (n=9) tamamen katıllyorum yanıtını vermiştir. katılımcıların " başkalarının beni onaylamayacağından korkarım" ifadesine zayıf ( $\bar{x}=2,520)$ düzeyde katıldıkları belirlenmiştir.

"Diğer insanlarm bende bir kusur bulacaklarndan korkarm" ifadesine katıllmciların, \%18,2'si ( $\mathrm{n}=56$ ) hiç katılmiyorum, \%35,7'si ( $\mathrm{n}=110)$ katılmiyorum, \%26,0'ı ( $\mathrm{n}=80)$ kararsızım, \%14,3'ü ( $\mathrm{n}=44)$ katiliyorum, $\% 5,8^{\prime} \mathrm{i}(\mathrm{n}=18)$ tamamen katıliyorum yanıtını vermiştir. Katıllımcların "diğer insanların bende bir kusur bulacaklarından korkarım" ifadesine zayıf $(\bar{x}=2,540)$ düzeyde katıldıklanı belirlenmiştir.

"Diğer insanlarn bakkımdaki düsünceleri beni rahatsız etmež" ifadesine katıllımcıların, \%6,5'i ( $\mathrm{n}=20)$ hiç katılmiyorum, \%30,5'i (n=94) katılmiyorum, \%36,0'1 ( $\mathrm{n}=111$ ) kararsızım, \%16,9'u (n=52) kattliyorum, $\% 10,1^{\prime} i(n=31)$ tamamen katıllyorum yanıtını vermiştir. Katılımcıların " diğer insanların hakkımdaki düşünceleri beni rahatsız etmez" ifadesine orta $(\bar{x}=2,940)$ düzeyde katıldıkları belirlenmiştir.

"Birileriyle konuşrken benim hakekrmda ne düşünecekleri ile ilgili endiselenirim" ifadesine katılımciların, \%15,3'ü $(\mathrm{n}=47)$ hiç katılmıyorum, \%33,1'i ( $\mathrm{n}=102)$ katılmıyorum, \%29,2'si ( $\mathrm{n}=90)$ kararsızım, \%18,2'si ( $\mathrm{n}=56)$ katılıyorum, \%4,2'si $(\mathrm{n}=13)$ tamamen katılıyorum yanıtını vermiştir. Katılımcıların " birileriyle konuşurken benim hakkımda ne düşünecekleri ile ilgili endişelenirim" ifadesine orta $(\bar{x}=2,630)$ düzeyde katıldıkları belirlenmiştir.

"Genellikle baskealar üzerinde nasıl bir iॄlenim buraktığmla ilgili olarak endise duyarm" ifadesine katılımcilarnn, $\% 11,01$ ' (n=34) hiç katılmıyorum, \%27,6's1 ( $\mathrm{n}=85)$ katılmıyorum, \%26,6's1 (n=82) kararsızım, \%28,6's1 $(\mathrm{n}=88)$ katıliyorum, \%6,2'si $(\mathrm{n}=19)$ tamamen katıllyorum yanıtını vermiştir. Katıllımcıların " genellikle başkaları üzerinde nasıl bir izlenim bıraktığımla ilgili olarak endişe duyarım" ifadesine orta $(\bar{x}=2,910)$ düzeyde katıldıkları belirlenmiştir.

"Eğer birisi benimle ilgili bir değerlendirmede bulunursa, bu beni çok fazla etkilemez" ifadesine katulımciların, $\% 8,8^{\prime} \mathrm{i}(\mathrm{n}=27)$ hiç katılmıyorum, \%30,2'si ( $\mathrm{n}=93$ ) katılmiyorum, \%38,0'1 ( $\mathrm{n}=117$ ) kararsızım, \%17,9'u $(\mathrm{n}=55)$ katıllyorum, \%5,2'si $(\mathrm{n}=16)$ tamamen katıllyorum yanıtını vermiştir. Katıllımcıların " eğer birisi benimle ilgili bir değerlendirmede bulunursa, bu beni çok fazla etkilemez" ifadesine orta $(\bar{x}=2,810)$ düzeyde katıldıkları belirlenmiştir.

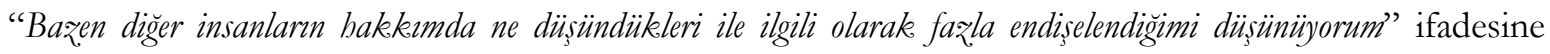
katılımcıların, \%17,2'si (n=53) hiç katılmıyorum, \%31,8'i (n=98) katılmıyorum, \%22,4'ü (n=69) kararsızım, $\% 22,4$ 'ü (n=69) katilıyorum, \%6,2'si (n=19) tamamen katılıyorum yanıtını vermiştir. Katılımcıların " bazen diğer insanların hakkımda ne düşündükleri ile ilgili olarak fazla endişelendiğimi düşünüyor um" ifadesine orta $(\bar{x}=2,690)$ düzeyde katıldıkları belirlenmiştir.

"Coğunlukla yanlss bir şey yapacağım ya da söyleyeceğim diye endişelenirim" ifadesine katıllmcıların, \%11,0'1 $(\mathrm{n}=34)$ hiç katılmıorum, \%31,8'i (n=98) katılmiyorum, \%20,5'i ( $\mathrm{n}=63)$ kararsızım, \%26,6's1 ( $\mathrm{n}=82)$ 
katıllyorum, \%10,1'i (n=31) tamamen katılıyorum yanıtını vermiştir. Katılımcıların " çoğunlukla yanlış bir şey yapacağım ya da söyleyeceğim diye endişelenirim" ifadesine orta $(\bar{x}=2,930)$ düzey de katıldıkları belirlenmiştir.

"Satın alma kararlarm destekleyecek önerileri bulmak için sosyal medya reklamlarm kullanyorum" ifadesine katılımciların, \%24,7'si ( $\mathrm{n}=76$ ) hiç katılmiyorum, \%23,4'ü ( $\mathrm{n}=72)$ katılmıorum, \%25,3'ü $(\mathrm{n}=78)$ kararsızım, \%22,7'si ( $\mathrm{n}=70)$ katıliyorum, \%3,9'u $(\mathrm{n}=12)$ tamamen katıllyorum yanıtını vermiştir. Katılımcıların "satın alma kararlarımı destekleyecek önerileri bulmak için sosyal medya reklamlarını kullanıyorum" ifadesine zayıf $(\bar{x}=2,580)$ düzeyde katıldıkları belirlenmiştir.

"Ürünler ve bizmetler bakkènda aymntıl bilgi almak için sosyal medya reklamlarm kullanyorum" ifadesine katılımciların, \%23,4'ü (n=72) hiç katılmıorum, \%26,0'1 (n=80) katılmıyorum, \%23,4'ü (n=72) kararsızım, $\% 22,4$ 'ü $(\mathrm{n}=69)$ katıllıyorum, \%4,9'u ( $\mathrm{n}=15)$ tamamen katıllyorum yanıtını vermiştir. Katılımcıların "ürünler ve hizmetler hakkında ayrıntılı bilgi almak için sosyal medya reklamlarını kullanıyorum" ifadesine zayıf ( $\bar{x}$ $=2,590$ ) düzeyde katıldıkları belirlenmiştir.

"Bilgi alı, doğru satın alma kararlar vermek için sosyal medya reklamlarm kullanyorum" ifadesine katıllimciların, $\% 20,5^{\prime} \mathrm{i}(\mathrm{n}=63)$ hiç katılmıyorum, \%23,1'i $(\mathrm{n}=71)$ katılmıyorum, \%27,9'u ( $\left.\mathrm{n}=86\right)$ kararsızım, \%24,4'ü $(\mathrm{n}=75)$ katıllyorum, \%4,2'si ( $\mathrm{n}=13)$ tamamen katılıyorum yanıtını vermiştir. Katılımcıların " bilgi alıp, doğru satın alma kararları vermek için sosyal medya reklamlarını kullanıyorum" ifadesine orta $(\bar{x}=2,690)$ düzeyde katıldıkları belirlenmiştir.

"Bir satun alma kararnda yer alan sorunlar nasıl çözeceğiniæi ögrenmek için sosyal medya reklamlarm kullanyyorum” ifadesine katılımcıların, \%24,7'si ( $\mathrm{n}=76$ ) hiç katılmıyorum, \%29,9'u ( $\mathrm{n}=92)$ katılmıorum, \%29,5'i (n=91) kararsızım, \%15,9'u (n=49) katıllyorum yanıtını vermiştir. Katılımcıların " bir satın alma kararında yer alan sorunları nasıl çözeceğinizi öğrenmek için sosyal medya reklamlarını kullanıyorum" ifadesine zayıf ( $\bar{x}=$ 2,370) düzeyde katıldıkları belirlenmiştir.

"Alacağım riski en aza indirmek, için sosyal medya reklamlarm kullanyorum" ifadesine katıllımciların, \%26,3'ü $(\mathrm{n}=81)$ hiç katılmıyorum, \%26,9'u ( $\mathrm{n}=83)$ katılmiyorum, \%29,9'u ( $\mathrm{n}=92)$ kararsızım, \%14,0'1 ( $\mathrm{n}=43)$ katılıyorum, \%2,9'u (n=9) tamamen katılıyorum yanıtını vermiştir. Katılımcıların " alacağım riski en aza indirmek için sosyal medya reklamlarını kullanıyorum" ifadesine zayıf $(\bar{x}=2,400)$ düzeyde katıldıkları belirlenmiştir.

"Sosyal medya reklamcllĭgnnn çok önemli olduğunu düşünüyorum" ifadesine katıllımcilann, \%12,0'1 (n=37) hiç katılmiyorum, \%8,1'i ( $\mathrm{n}=25)$ katılmiyorum, \%26,9'u ( $\mathrm{n}=83)$ kararsızım, \%32,5'i ( $\mathrm{n}=100)$ katiliyorum, $\% 20,5^{\prime} \mathrm{i}(\mathrm{n}=63)$ tamamen katılıyorum yanıtını vermiştir. Katılımcıların "sosyal medya reklamcilığının çok önemli olduğunu düşünüyorum" ifadesine yüksek $(\bar{x}=3,410)$ düzeyde katıldıkları belirlenmiştir.

"Sosyal medya reklamciluğna karşs genel tutumum olduksca olumludur" ifadesine katılımciların, \%18,8'i (n=58) hiç katılmıyorum, \%22,4'ü ( $\mathrm{n}=69)$ katılmiyorum, \%31,8'i $(\mathrm{n}=98)$ kararsızım, \%20,5'i $(\mathrm{n}=63)$ katiliyorum, $\% 6,5$ 'i $(n=20)$ tamamen katılıyorum yanıtını vermiştir. Katılımcıların "sosyal medya reklamcıllğına karşı genel tutumum oldukça olumludur" ifadesine orta $(\bar{x}=2,730)$ düzeyde katıldıkları saptanmıştır.

"Sosyal medya reklamciluğ bakkemda genel fikrim olumlu" ifadesine katılımcların, \%18,5'i ( $\mathrm{n}=57)$ hiç katılmıyorum, \%20,5'i (n=63) katılmiyorum, \%28,6's1 ( $\mathrm{n}=88$ ) kararsızım, \%25,3'ü ( $\mathrm{n}=78$ ) kattliyorum, $\% 7,1^{\prime} \mathrm{i}(\mathrm{n}=22)$ tamamen katıliyorum yanıtını vermiştir. Katılımcıların "sosyal medya reklamcilı̆ı hakkında genel fikrim olumlu" ifadesine orta ( $\bar{x}=2,8$ 20) düzeyde katıldıkları belirlenmiştir.

"Sosyal medyada gösterilen ürünlerin afiss reklamlarm severim" ifadesine katıllmcıların, \%24,4'ü ( $\mathrm{n}=75)$ hiç katılmiyorum, \%13,6's1 ( $\mathrm{n}=42)$ katılmiyorum, \%28,6's1 ( $\mathrm{n}=88)$ kararsızım, \%27,3'ü ( $\mathrm{n}=84)$ kattliyorum, $\% 6,2$ 'si $(\mathrm{n}=19)$ tamamen katılıyorum yanıtını vermiştir. Katılımcıların "sosyal medyada gösterilen ürünlerin afiş reklamlarını severim" ifadesine orta $(\bar{x}=2,770)$ düzeyde katıldıkları belirlenmiştir.

"Sik sı sosyal medyadaki banner reklamlarn tıklarm" ifadesine katılımcıların, \%42,9'u (n=132) hiç katilmiyorum, \%30,5'i (n=94) katılmiyorum, \%18,5'i $(\mathrm{n}=57)$ kararsızım, \%7,5'i $(\mathrm{n}=23)$ kat1lyorum, \%0,6's1 $(\mathrm{n}=2)$ tamamen katılıyorum yanıtını vermiştir. katılımcıların "sık sık sosyal medyadaki banner reklamlarını tıklarım" ifadesine zayıf ( $\bar{x}=1,930)$ düzeyde katıldıkları belirlenmiştir.

"Sosyal medya profilimde gösterilen reklamları sık sık tıkliyorum" ifadesine katılımciların, \%42,9'u ( $\mathrm{n}=132)$ hiç katılmıyorum, \%30,8'i (n=95) katılmiyorum, \%16,9'u (n=52) kararsızım, \%7,8'i (n=24) katillyorum, \%1,6's1 
ÜLKER

Olumsuz Değerlendirilme Korkusu ile Sosyal Medya Reklamlarına Yönelik Tutum İlişkisi

$(\mathrm{n}=5)$ tamamen katılıyorum yanıtını vermiştir. Katılımcıların "sosyal medya profilimde gösterilen reklamları sık sık tıklıyorum” ifadesine zayıf ( $\bar{x}=1,940)$ düzeyde katıldıkları belirlenmiştir.

Tablo 3. Olumsuz Değerlendirilme Korkusu ve Sosyal Medya Reklamlarna Karşı Tutum Puan Ortalamaları

\begin{tabular}{l|l|l|l|l|l}
\hline & N & Ort & Ss & Min. & Max. \\
\hline Olumsuz Değerlendirilme Korkusu & 308 & 2,824 & 0,754 & 1,000 & 5,000 \\
\hline Sosyal Medya Reklamlarına Yönelik Tüketici Kanaati & 308 & 2,567 & 0,862 & 1,000 & 4,450 \\
\hline Sosyal Medya Reklamlarını Tercih Etme Nedenleri & 308 & 2,526 & 0,991 & 1,000 & 4,600 \\
\hline Sosyal Medya Reklamlarına Karşı Genel Tutum & 308 & 2,602 & 0,907 & 1,000 & 4,670 \\
\hline
\end{tabular}

Katılımcıların “olumsuz değerlendirilme korkusu” ortalaması orta 2,824 $\pm 0,754$ (Min=1; Maks=5),

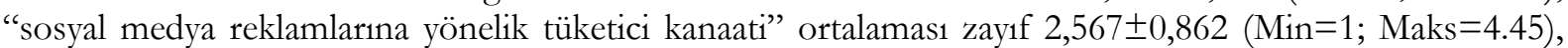

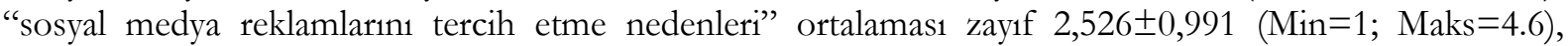
"sosyal medya reklamlarına karşı genel tutum" ortalaması orta 2,602 $\pm 0,907$ (Min=1; Maks=4.67), olarak saptanmıştır.

Tablo 4. Olumsuz Değerlendirilme Korkusu ve Sosyal Medya Reklamlarna Karşı Tutum Puanlarmın Tanımlayıcı Özelliklere Göre Farklulasma Durumu

\begin{tabular}{|c|c|c|c|c|c|}
\hline $\begin{array}{l}\text { Demografik } \\
\text { Özellikler }\end{array}$ & n & $\begin{array}{c}\text { Olumsuz } \\
\text { Değerlendirilme } \\
\text { Korkusu }\end{array}$ & $\begin{array}{c}\text { Sosyal Medya } \\
\text { Reklamlarına } \\
\text { Yönelik Kanaat }\end{array}$ & $\begin{array}{c}\text { Sosyal Medya } \\
\text { Reklamlarının Tercih } \\
\text { Edilme Nedenleri }\end{array}$ & $\begin{array}{c}\text { Sosyal Medya } \\
\text { Reklamlarına Karşı } \\
\text { Genel Tutum }\end{array}$ \\
\hline Cinsiyet & & Ort $\pm S S$ & Ort $\pm S S$ & Ort $\pm S S$ & Ort $\pm \mathrm{SS}$ \\
\hline Erkek & 153 & $3,000 \pm 0,732$ & $2,694 \pm 0,869$ & $2,702 \pm 0,960$ & $2,687 \pm 0,895$ \\
\hline Kadin & 155 & $2,650 \pm 0,737$ & $2,442 \pm 0,840$ & $2,352 \pm 0,995$ & $2,517 \pm 0,914$ \\
\hline $\mathrm{t}=$ & & 4,183 & 2,586 & 3,139 & 1,651 \\
\hline $\mathrm{p}=$ & & 0,000 & 0,010 & 0,002 & 0,100 \\
\hline Yaş & & Ort $\pm S S$ & Ort $\pm S S$ & Ort $\pm S S$ & Ort $\pm \mathrm{SS}$ \\
\hline $20 \mathrm{Ve}$ Alt 1 & 70 & $2,962 \pm 0,688$ & $2,636 \pm 0,926$ & $2,569 \pm 0,886$ & $2,693 \pm 1,126$ \\
\hline $21-30$ & 207 & $2,796 \pm 0,796$ & $2,559 \pm 0,863$ & $2,513 \pm 1,063$ & $2,597 \pm 0,846$ \\
\hline 30 Üzeri & 31 & $2,698 \pm 0,560$ & $2,466 \pm 0,704$ & $2,516 \pm 0,704$ & $2,425 \pm 0,734$ \\
\hline $\mathrm{F}=$ & & 1,765 & 0,445 & 0,083 & 0,945 \\
\hline $\mathrm{p}=$ & & 0,173 & 0,641 & 0,920 & 0,390 \\
\hline $\begin{array}{l}\text { Yükseköğretim } \\
\text { Seviyesi }\end{array}$ & & Ort $\pm S S$ & Ort $\pm S S$ & Ort $\pm S S$ & Ort $\pm S S$ \\
\hline Önlisans & 26 & $2,892 \pm 1,086$ & $2,696 \pm 0,943$ & $2,723 \pm 0,849$ & $2,673 \pm 1,102$ \\
\hline Lisans & 171 & $2,796 \pm 0,728$ & $2,639 \pm 0,858$ & $2,572 \pm 0,958$ & $2,694 \pm 0,943$ \\
\hline Lisansüstü & 111 & $2,851 \pm 0,705$ & $2,428 \pm 0,839$ & $2,409 \pm 1,066$ & $2,443 \pm 0,778$ \\
\hline $\mathrm{F}=$ & & 0,293 & 2,351 & 1,475 & 2,694 \\
\hline $\mathrm{p}=$ & & 0,746 & 0,097 & 0,231 & 0,069 \\
\hline Medeni Durum & & Ort $\pm S S$ & Ort $\pm S S$ & Ort $\pm S S$ & Ort $\pm \mathrm{SS}$ \\
\hline Evli & 29 & $2,699 \pm 0,830$ & $2,467 \pm 0,997$ & $2,524 \pm 1,158$ & $2,420 \pm 0,925$ \\
\hline Bekar & 279 & $2,837 \pm 0,746$ & $2,578 \pm 0,848$ & $2,526 \pm 0,975$ & $2,621 \pm 0,905$ \\
\hline $\mathrm{t}=$ & & $-0,936$ & $-0,657$ & $-0,010$ & $-1,137$ \\
\hline $\mathrm{p}=$ & & 0,350 & 0,512 & 0,992 & 0,256 \\
\hline Çalışma Durumu & & Ort $\pm S S$ & Ort $\pm S S$ & Ort $\pm S S$ & Ort $\pm S S$ \\
\hline Evet & 115 & $2,600 \pm 0,789$ & $2,602 \pm 0,963$ & $2,565 \pm 1,096$ & $2,633 \pm 0,967$ \\
\hline Hayır & 193 & $2,957 \pm 0,701$ & $2,546 \pm 0,798$ & $2,503 \pm 0,925$ & $2,583 \pm 0,871$ \\
\hline $\mathrm{t}=$ & & $-4,124$ & 0,551 & 0,536 & 0,471 \\
\hline $\mathrm{p}=$ & & 0,000 & 0,600 & 0,608 & 0,638 \\
\hline Aylık Gelir & & Ort \pm SS & Ort \pm SS & Ort \pm SS & Ort $\pm \mathrm{SS}$ \\
\hline 1000 ve Alt1 & 123 & $2,985 \pm 0,750$ & $2,651 \pm 0,792$ & $2,533 \pm 0,950$ & $2,749 \pm 0,834$ \\
\hline $1001-2000$ & 60 & $2,717 \pm 0,752$ & $2,352 \pm 0,722$ & $2,257 \pm 0,912$ & $2,431 \pm 0,747$ \\
\hline $2001-3000$ & 54 & $2,722 \pm 0,555$ & $2,653 \pm 1,031$ & $2,707 \pm 0,982$ & $2,608 \pm 1,194$ \\
\hline 3000 Üzeri & 71 & $2,713 \pm 0,853$ & $2,539 \pm 0,929$ & $2,603 \pm 1,102$ & $2,486 \pm 0,878$ \\
\hline $\mathrm{F}=$ & & 3,168 & 1,860 & 2,250 & 2,210 \\
\hline $\mathrm{p}=$ & & 0,025 & 0,136 & 0,083 & 0,087 \\
\hline PostHoc $=$ & & \multicolumn{4}{|c|}{$1>2,1>3,1>4(\mathrm{p}<0.05)$} \\
\hline $\begin{array}{l}\text { Günlük İnternette } \\
\text { Geçirilen Saat }\end{array}$ & & Ort $\pm S S$ & Ort $\pm S S$ & Ort $\pm S S$ & Ort $\pm S S$ \\
\hline 2 Saatten $\mathrm{Az}$ & 44 & $2,944 \pm 0,861$ & $2,399 \pm 0,926$ & $2,409 \pm 0,993$ & $2,390 \pm 1,041$ \\
\hline 3-5 Saat & 174 & $2,824 \pm 0,648$ & $2,541 \pm 0,823$ & $2,503 \pm 0,946$ & $2,573 \pm 0,829$ \\
\hline 6-8 Saat & 65 & $2,547 \pm 0,678$ & $2,794 \pm 0,918$ & $2,766 \pm 1,156$ & $2,818 \pm 0,951$ \\
\hline 8 Saat Üzeri & 25 & $3,331 \pm 1,091$ & $2,455 \pm 0,800$ & $2,264 \pm 0,727$ & $2,613 \pm 0,999$ \\
\hline $\mathrm{F}=$ & & 7,517 & 2,288 & 2,110 & 2,112 \\
\hline $\mathrm{p}=$ & & 0,000 & 0,079 & 0,099 & 0,099 \\
\hline PostHoc= & & $\begin{array}{l}4>1,4>2,1>3 \\
>3,4>3(\mathrm{p}<0.05)\end{array}$ & & & \\
\hline
\end{tabular}


Elde edilen veriler doğrultusunda; erkek katılımcıların olumsuz değerlendirilme korkusu puanları $(\mathrm{x}=3,000)$, kadınların olumsuz değerlendirilme korkusu puanlarından $(\mathrm{x}=2,650)$ yüksek bulunmuştur $(\mathrm{t}=4,183 ; \mathrm{p}=0<0.05)$. Elde edilen veriler doğrultusunda erkek katılımciların, kadınlara oranla daha çok olumsuz değerlendirilme korkusu yaşadıkları söylenebilir. Bu bağlamda H1a: 'olumsuz değerlendirilme korkusu ile katılımcıların cinsiyetleri arasında fark vardır.' hipotezi desteklenmiştir. Ayrıca erkek katılımcıların sosyal medya reklamlarına yönelik kanaat puanları $(\mathrm{x}=2,694)$, kadın katılımcıların sosyal medya reklamlarına yönelik kanaat puanlarından $(\mathrm{x}=2,442)$ yüksektir $(\mathrm{t}=2,586 ; \mathrm{p}=0.01<0.05)$. Bunun yanı sira erkek katılımciların sosyal medya reklamlarını tercih etme nedenleri puanları $(\mathrm{x}=2,702)$, kadınların sosyal medya reklamlarını tercih etme nedenleri puanlarından $(\mathrm{x}=2,352)$ yüksek bulunmuştur $(\mathrm{t}=3,139$; $\mathrm{p}=0.002<0.05)$. Bu bağlamda katılımcıların sosyal medya reklamlarına karşı genel tutum puanlarının cinsiyet değişkenine göre anlamlı bir farklıllğın olmadığı görülmektedir ( $\mathrm{p}>0.05)$.

Yapılan analize göre katılımcıların 'olumsuz değerlendirilme korkusu', 'sosyal medya reklamlarına yönelik kanaati', 'sosyal medya reklamlarını tercih etme nedenleri' ve 'sosyal medya reklamlarına karşı genel tutum' puanları yaş değiş̧kenine göre anlamlı hiçbir farklılık göstermemektedir ( $\mathrm{p}>0.05)$. Bu bağlamda araştırmadaki Hipotez 1 b desteklenmemiştir. Ayrıca elde edilen veriler doğrultusunda katılımcıların olumsuz değerlendirilme korkusu, sosyal medya reklamlarına yönelik kanaati, sosyal medya reklamlarını tercih etme nedenleri, sosyal medya reklamlarına karşı genel tutum puanları yükseköğretim seviyesi değişkenine göre de anlamlı farkllılı göstermemektedir ( $\mathrm{p}>0.05)$. Bu sebeple araştırmadaki 'olumsuz değerlendirilme korkusu ile katılımcıların eğitim seviyeleri arasında fark vardır' H1c desteklenmemiştir. Elde edilen bilgiler ışığında katılımcıların olumsuz değerlendirilme korkusu, sosyal medya reklamlarına yönelik kanaat, sosyal medya reklamlarını tercih etme nedenleri ve sosyal medya reklamlarına karşı genel tutum puanları medeni durum değişkenine göre de anlamlı bir farklılığın olmadığı görülmektedir ( $\mathrm{p}>0.05$ ). Bu bağlamda Hipotez 1d desteklenmemiştir. Araştırmada çalışanların olumsuz değerlendirilme korkusu puanları $(\mathrm{x}=2,600)$, çalışmayanların puanlarından $(\mathrm{x}=2,957)$ düşüktür $(\mathrm{t}=-4,124 ; \mathrm{p}=0<0.05)$. Çalışmaya göre iş hayatında aktif yer alan katılımcıların olumsuz değerlendirilme korkusunu daha az yaşadığı görülmektedir. $\mathrm{Bu}$ sebeple araştırmadaki 'olumsuz değerlendirilme korkusu ile katılımcıların çalışma durumları arasında fark vardır' Hipotezi 1e desteklenmiştir. Ayrıca katılımcıların sosyal medya reklamlarına yönelik kanaati, sosyal medya reklamlarını tercih etme nedenleri ve sosyal medya reklamlarına karşı genel tutum puanları çalışma durumu değişkenine göre anlamlı farklılık göstermemektedir ( $\mathrm{p}>0.05)$. Yapılan çalışmaya göre katılımcıların olumsuz değerlendirilme korkusu puanları aylık gelir değişkenine göre anlamlı farklılık göstermektedir $(\mathrm{F}=3,168 ; \mathrm{p}=0.025<0.05)$. Bu bağlamda elde edilen veriler doğrultusunda; 'olumsuz değerlendirilme korkusu ile katılımcıların aylık gelir durumları arasında fark vardır' H1f desteklenmiştir. Bu farkın nedeni aylık geliri 1000 TL ve altı olanların olumsuz değerlendirilme korkusu puanlarının, aylık geliri 1001-2000 TL olanların puanlarından yüksek olmasıdır ( $<<0.05)$. Katılımcılardan aylık geliri 1000 TL ve altı olanların olumsuz değerlendirilme korkusu puanları, aylık geliri 2001-3000 TL olanların olumsuz değerlendirilme korkusu puanlarından yüksektir $(\mathrm{p}<0.05)$. Ayrıca aylık geliri $1000 \mathrm{TL}$ ve altı olanların olumsuz değerlendirilme korkusu puanlarının, aylık geliri 3000 TL üzeri olanların puanlarından yüksek olduğu görülmektedir $(\mathrm{p}<0.05)$. Bunun yanı sıra araştırmada elde edilen bulgular, katılımcıların sosyal medya reklamlarına yönelik kanaatleri, sosyal medya reklamlarını tercih etme nedenleri ve sosyal medya reklamlarına karşı genel tutum puanları aylık gelir değişkenine göre anlamlı farklılık göstermediği görülmektedir ( $\mathrm{p}>0.05)$.

Araştırmada katılımcıların günlük internette geçirdikleri süreler de incelenmiştir. Bu bağlamda elde edilen verilere göre, katılımcıların olumsuz değerlendirilme korkusu puanları günlük internette geçirilen saat değişkenine göre anlamlı farklılık göstermektedir $(F=7,517 ; \mathrm{p}=0<0.05)$. Elde edilen farkın nedeni; günlük internette 8 saat ve üzeri geçirenlerin olumsuz değerlendirilme korkusu puanlarının, günlük internette 2 ve daha az saat geçirenlerin olumsuz değerlendirilme korkusu puanlarından yüksek olmasıdır $(\mathrm{p}<0.05)$. Ayrıca günlük internette 8 ve üzeri saat geçirenlerin olumsuz değerlendirilme korkusu puanlarının, günlük internette 3-5 saat geçirilenlere olan puanlarından yüksek bulunmuştur $(\mathrm{p}<0.05)$. Elde edilen bir diğer veri de günlük internette 2 ve daha azını geçirenlerin olumsuz değerlendirilme korkusu puanlarının, günlük internette 6-8 saat geçirilenlere oranla puanlarının daha yüksek olmasıdır $(\mathrm{p}<0.05)$. Araştırmada günlük internette 3-5 saat geçirenlerin olumsuz değerlendirilme korkusu puanları, günlük internette 6-8 saat geçirenlerin puanlarından yüksek bulunmuştur $(\mathrm{p}<0.05)$. Ayrıca günlük internette 8 ve üzeri saat geçirenlerin olumsuz değerlendirilme korkusu puanları, günlük internette 6-8 saat geçirenlerin olumsuz değerlendirilme korkusu puanlarından yüksek bulunmuştur $(\mathrm{p}<0.05)$. Bu bağlamda 'olumsuz değerlendirilme korkusu ile katılımciların günlük internette geçirilen saatleri arasında fark vardır’ H1g 
desteklenmiştir. Bununla birlikte katılımcıların sosyal medya reklamlarına yönelik kanaati, sosyal medya reklamlarını tercih etme nedenleri ve sosyal medya reklamlarına karşı genel tutum puanları günlük internette geçirilen saat değişkenine göre anlamlı farklılık göstermemektedir ( $\mathrm{p}>0.05)$.

Tablo 5. Olumsuz Değerlendirilme Korkusu ve Sosyal Medya Reklamlarna Karşı Tutum Arasmdaki Korelasyon Analizi

\begin{tabular}{l|l|c}
\hline & & Olumsuz Değerlendirilme Korkusu \\
\hline \multirow{2}{*}{ Sosyal Medya Reklamlarına Yönelik Tüketici Kanaati } & $\mathrm{r}$ & 0,066 \\
\cline { 2 - 3 } & $\mathrm{p}$ & 0,250 \\
\hline \multirow{2}{*}{ Sosyal Medya Reklamlarını Tercih Etme Nedenleri } & $\mathrm{r}$ & $0,144^{*}$ \\
\cline { 2 - 3 } & $\mathrm{p}$ & 0,012 \\
\hline \multirow{2}{*}{ Sosyal Medya Reklamlarına Karşı Genel Tutum } & $\mathrm{r}$ & $-0,016$ \\
\cline { 2 - 3 } & $\mathrm{p}$ & 0,773 \\
\hline
\end{tabular}

$*<0,05 ; * *<0,01$

Araştırmada, 'olumsuz değerlendirilme korkusu', 'sosyal medya reklamlarına yönelik kanaat', 'sosyal medya reklamlarını tercih etme nedenleri' ve 'sosyal medya reklamlarına karşı genel tutum', arasında korelasyon analizi yapılmıştır. Elde edilen veriler doğrultusunda; katılımcıların olumsuz değerlendirilme korkusu ile sosyal medya reklamların tercih etme nedenleri arasında $r=0.144$ pozitif $(p=0,012<0.05)$ korelasyon bulunmuştur. Fakat korelasyon düşük bulunduğu için 'olumsuz değerlendirilme korkusu ile sosyal medya reklamlarına karşı tutumun alt boyutu olan sosyal medya reklamlarının tercih edilme nedenleri arasında anlamlı bir ilişski vardır' Hipotez 2a desteklenmemektedir. Fakat elde edilen diğer verilere göre değişkenler arasındaki ilişkiler istatistiksel olarak anlamlı değildir ( $\mathrm{p}>0.05)$. Bu bağlamda 'olumsuz değerlendirilme korkusu ile sosyal medya reklamlarına karşı genel tutum arasında anlamlı bir ilişki vardır' Hipotez 2 ve 'olumsuz değerlendirilme korkusu ile sosyal medya reklamlarına karşı tutumun alt boyutu olan sosyal medya reklamlarına yönelik tüketici kanaati arasında anlamlı bir ilişki vardır' Hipotez $2 \mathrm{~b}$ desteklenmemiştir.

\section{Tartı̧̧ma, Sonuç ve Öneriler}

Sosyal bir varlık olan insan, yaşamını sürdürebilmek için diğer insanlarla iletişim kurmak zorundadır. Fakat insanlar, diğerleriyle iletişim kurarken beğenilme, onaylanma ve kabul görme gibi davranışlar beklemektedir. Bu bekleyiş bazı insanlarda büyük bir korku ve kaygiya sebep olmaktadır. Bu durum da bazı bireylerde olumsuz değerlendirilme korkusunu ortaya çıkarmaktadır. Olumsuz değerlendirilme korkusuna sahip olan bireyler de kendilerini diğer insanlardan izole etmeye çalışmaktadır. Bu sebeple mahremiyetini koruyabildiği ve istediği ölçüde kişisel bilgilerini paylaşttğı sosyal medyaya yönelmektedir. Yapılan araştırmalar da bu durumu destekler doğrultudadır. Diğer bir deyişle olumsuz değerlendirilme korkusuna sahip bireyler ile sosyal medya kullanım sıklığı arasında bir ilişki bulunmaktadır.

Yukarıdaki bilgiler doğrultusunda olumsuz değerlendirilme korkusuna sahip bireylerin sık sık sosyal medya kullandığı görülmektedir. Bu bağlamda bu bireylerin sosyal medya reklamlarına da sıkça maruz kaldığ1 düşünülebilmektedir. Bu sebeple araştırmanın amacı olumsuz değerlendirilme korkusu yaşayan bireylerin sosyal medya reklamlarına yönelik tutumları arasındaki ilişkinin olup olmadığının irdelenmesidir. Buna ek olarak olumsuz değerlendirilme korkusuna sahip bireylerin sosyal medya reklamlarına yönelik tutumun alt boyutlarına olan ilişkileri de incelenmiştir. Ayrıca çalışmada olumsuz değerlendirilme korkusu ile tüketicilerin demografik özellikleri arasında anlamlı bir farkın olup olmadığı da irdelenen konular arasındadır. Bu amaçlar doğrultusunda sosyal medyayı en çok kullanan üniversite öğrencileri araştırmanın ana kütlesi olarak seçilmiş olup, kolayda örneklem yöntemi ile araştırmanın örneklem kütlesi sadece Marmara Üniversitesi öğrencilerinden oluşturulmuştur. Bu bağlamda Marmara Üniversitesinde okuyan 308 öğrenciye yüz yüze anket uygulanmıştır. Elde edilen veriler sonucunda, katıllımcıların olumsuz değerlendirilme korkusu ile demografik özellikleri arasında anlamlı bir farkın olduğu görülmektedir. Araştırmada katılımcıların olumsuz değerlendirilme korkularıyla; cinsiyet, çalışma, aylık gelir ve günlük internette geçirilen durumları arasında anlamlı bir farkın olduğu belirlenmiştir. Elde edilen veriler doğrultusunda araştırmaya katılan erkeklerin, kadın katılımcılara oranla daha çok olumsuz değerlendirilme korkusu yaşadıkları söylenebilir. Bu bağlamda araştırmadan elde edilen verilerin Carleton, Collimore ve Asmundson'un (2007, s. 138) yapmış olduğu araştırmadaki verilerle benzer olduğu söylenebilir. Ayrıca katılımcıların olumsuz değerlendirilme korkularıyla, cinsiyet farklılıklarının olduğu Habke ve arkadaşları (1997) ile Turk ve arkadaşlarının (1998) araştırmalarının verileriyle de örtüşmektedir. Bunun yanı sıra araşıırmada iş hayatında aktif olan katılımcıların olumsuz değerlendirilme korkusunun pasif olanlara oranla 
daha az olduğu görülmektedir. Bu bağlamda çalışan katılımcıların daha az değerlendirilme korkusu yaşadıkları söylenebilir. Bu durum gelir durumunda da görülmektedir. Gelir durumu yüksek olan katılımcıların, düşük olanlara oranla daha az değerlendirilme korkusuna sahip oldukları görülmektedir.

Araştırmaya ek olarak; olumsuz değerlendirilme korkusu ile sosyal medya reklamlarına karşı genel tutum arasında anlamlı bir ilişkinin olup olmadığı da irdelenmiştir. Bu bağlamda çalışmada, 'olumsuz değerlendirilme korkusu', 'sosyal medya reklamlarına yönelik kanaat', 'sosyal medya reklamlarını tercih etme nedenleri' ve 'sosyal medya reklamlarına karşı genel tutum', arasında korelasyon analizi yapılmıştır. Elde edilen veriler doğrultusunda; katılımcıların olumsuz değerlendirilme korkusu ile sosyal medya reklamlarını tercih etme nedenleri arasında anlamlı bir ilişkiye rastlanmamıştır. Ayrıca yapılan araştırmaya göre olumsuz değerlendirilme korkusu ile sosyal medya reklamlarına karşı tutumun alt boyutu olan sosyal medya reklamlarının tercih edilme nedenleri arasında da anlamlı bir ilişkinin olmadığı görülmektedir. Bunlara ek olarak araştırmada, olumsuz değerlendirilme korkusu ile sosyal medya reklamlarına karşı tutumun alt boyutu olan sosyal medya reklamlarına yönelik tüketici kanaati arasında da anlamlı bir ilişkiye rastlanmamaktadır. Bu bilgiler ışı̆ı̆nda olumsuz değerlendirilme korkusuna sahip bireylerin sosyal medya reklamlarına olan tutumları arasında bir ilişkinin olmadığı sonucuna varılmıştır.

Araştırmada sadece olumsuz değerlendirilme korkusu yaşayan bireylerin sosyal medya reklamlarına olan tutumları incelenmiştir. Fakat gelecek çalışmalar da olumsuz değerlendirilme korkusu yaşayan bireylerin, satın alma davranışlarının nasıl olduğu da incelenebilir. Bu bağlamda çalışmanın gelecekte yapılacak çalışmalara yol gösterici olacağına inanılmaktadır. Ayrıca çalışmanın, markaların hedef kitlelerinin olumsuz değerlendirilme korkusu yaşayıp yaşamadıklarına bakarak, sosyal medya reklamlarıyla ilgili stratejilerini belirlemelerinde de yol göstereceği olacağını düşünülmektedir.

\section{Etik Beyan}

“Olumsuz Değerlendirilme Korkusu ile Sosyal Medya Reklamlarna Yönelik Tutum İlişkisi” başlıklı çalışmanın yazım sürecinde bilimsel kurallara, etik ve alıntı kurallarına uyulmuş; toplanan veriler üzerinde herhangi bir tahrifat yapılmamış ve bu çalışma herhangi başka bir akademik yayın ortamına değerlendirme için gönderilmemiştir. Bu çalışma kapsamında gerçekleştirilen araştırma Marmara Üniversitesi Sosyal Bilimler Araştırma Etik Kurulu'nun 09.11.2020 tarih ve 2020/27 sayılı Etik Kurul Değerlendirme Raporu ile etik açıdan uygun bulunmuştur.

\section{Kaynakça}

Aktan, E. (2018). Sosyal medya ve sosyal kaygı: sosyal medya kullanıcıları üzerine bir araştırma. Selçuk İleţ̦ism, 11(2), $35-53$.

Akyüz, A.M., Ayyldız, H. ve Yetim, F. (2007). Olumsuz değerlendirilme korkusu ile ani-kompulsif satın alma davranışı ilişkisinde yatay bireysellik ve/veya normatif uyumluluğun olası etkilerinin incelenmesi. Karadeniz Teknik. Üniversitesi Sosyal Bilimler Enstitiusü Sosyal Bilimler Dergisi, 7(14), 261-274.

Amichai-Hamburger, Y. ve Barak, A. (2009). Internet and Well-being. İçinde Y. Amichai-Hamburger (Edt.), Technology and psychological well-being (ss.34-76). Cambridge: Cambridge University Press.

Caplan, S. (2002). Problematic internet use and psychosocial well-being: development of a theory-based cognitivebehavioral measurement instrument. Computers in Human Behavior, 18, 553-575.

Caplan, S. (2007). Relations among loneliness, social anxiety and problematic internet use. Cyberpsychology \& Behavior, 10(2), 234-242.

Carleton, N. R., Collimore, K.C. ve Asmundson, G.J. (2007). Social anxiety and fear of negative evaluation: construct validity of the BFNE-II. Journal of Anxiety Disorders, 21, 131-141.

Çakmak, V. (2014). İletişim kaygısının sosyal medya kullanımı üzerine olan etkisi: üniversite öğrencileri üzerine örnek olay incelemesi (Doktora Tezi). Selçuk Üniversitesi, Sosyal Bilimler Enstitüsü, Konya.

Çam, S., Sevimli, D. ve Yerlikaya, E. (2010). Olumsuz değerlendirilmekten korkma ölçeği’ne (ODKÖ) ilişkin bir geçerlik ve güvenirlik çalışması. Cukurova Üniversitesi Sosyal Bilimler Enstitiisï Dergisi, 19(1), 132-140.

Çetin, A. B. ve Ceyhan, A. A. (2014). Ergenlerin internette kimlik denemeleri ve problemli internet kullanım davranışları. The Turkish Journal on Addictions, 1(2), 5-46.

Çetin, B., Doğan, T. ve Sapmaz, F. (2010). Olumsuz değerlendirilme korkusu ölçeği kısa formu'nun Türkçe uyarlaması: geçerlik ve güvenirlik çalışması. Eğitim ve Bilim, 35(156), 205-216.

Değer, K. (2018). Mahremiyetin sosyal medyada kullanımı: magazin dünyası üzerinden bir değerlendirme. Akademik Bakess Dergisi, (70), 166-176.

Erkan, Z., Güçray, S. Ve Çam, S. (2002). Ergenlerin sosyal kaygı düzeylerinin ana baba tutumları ve cinsiyet açısından incelenmesi. Cukurova Üniversitesi Sosyal Bilimler Enstitïsï Dergisi, 10(10), 64-75. 
Habke, M., Hewitt, P., Norton, G. R. ve Asmundson, G. (1997). The social phobia and social Interaction anxiety scales: an exploration of the dimensions of social anxiety and sex differences in structure and relations with Pathology. Journal of Psychopathology and Behavioral Assessment, 19(1), 21-39.

Huan, V. S., Ang, R. P. ve Chye, S. (2014). Loneliness and shyness in adolescent problematic internet users: the role of social anxiety. Child Youth Care Forum, 43(5), 539-551.

Irmak, M. (2015). Ortä̈gretim ögrencilerinin olumsuz değerlendirilme korkusu ve ögrenmeye iliskin tutumlarmm incelenmesi (Yüksek Lisans Tezi). Erciyes Üniversitesi, Eğitim Bilimleri Enstitüsü, Kayseri.

Karabulut, E. O. ve Bahadır, Z. (2013). Assessment of fear of negative evaluation levels and empathic tendency levels of national junior judo team. Nigde University Journal of Physical Education And Sport Sciences, 7(2), 108-115.

Koçak, G. N. (2012). Bireylerin sosyal medya kullanım davranışlarmm ve motivasyonlarmın kullanımlar ve doyumlar yaklaşımı bağlaminda incelenmesi: Eskişehir'de bir uygulama (Doktora Tezi). Anadolu Üniversitesi, Sosyal Bilimler Enstitüsü, Eskişehir.

Köse, E., Bayköse, N., Turan, E. B. ve Lapa, T. Y. (2016). Düzenli egzersiz yapan bireylerde olumsuz değerlendirilme korkusunun vücut alg1larını belirlemedeki rolü. Mediterranean Journal of Humanities, 5(2), 351-360.

Kurtuluş, K. (2010). Araștırma yöntemleri. İstanbul: Türkmen Kitabevi.

Naresh, K. M. ve Birks, D. F. (2000). Marketing research an applied approach, Prentice Hall.

Ömür, Y, E., Aydın, R. ve Argon, T. (2014). Olumsuz değerlendirilme korkusu ve akademik sahtekârlık. Eğitim ve Insani Bilimler Dergisi: Teori ve Uygulama, 5(9), 131-149.

Vural, B. A. ve Bat, M. (2010). Yeni bir iletişim ortamı olarak sosyal medya: Ege Üniversitesi İletişim Fakültesine yönelik bir araştırma. Journal of Yaşar University, 20(5), 3348-3382.

Watson, D. ve Friend, R. (1969). Measurement of social-evaluative anxiety. Journal of Consulting and Clinical Psychology,33(4), 448-457.

Weeks, J. W., Heimberg, R. G. ve Rodebaugh, T. L. (2008). The fear of positive evaluation scale: assessing a proposed cognitive component of social anxiety. Journal of Anxiety Disorders, 22, 44-55.

Wells, A., Clark, D. M., Salkovskis, P., Ludgate, J., Hackmann, A. ve Gelder, M. (1995). Social phobia: the role of insituation safety behaviors in maintaining anxiety and negative beliefs. Behavior Therapy, 26 (1), 153-161.

Wentzel, K. R. (2003). Sociometric status and adjustment in middle school: a longitudinal study. The Journal of Early Adolescence, 23(5), 5-28.

Woods, H. C., \& Scott, H. (2006). \#Sleepyteens: social media use in adolescence is associated with poor sleep quality, anxiety, depression and low self-esteem. Journal of Adolescence, 51, 41-49.

Yen, J.-Y., Yen, C.-F., Chen, C.-S., Wang, P.-W., Chang, Y.-H. ve Ko, C.-H. (2012). Social anxiety in online and reallife interaction and their associated factors. Cyberpsychology, behavior, and social networking, 15 (1), 7-12.

Zorbaz, O. (2013). Lise öğrencilerinin problemli internet kullanımının sosyal kayg1 ve akran ilişkileri açısından incelenmesi (Yüksek Lisans Tezi). Hacettepe Üniversitesi, Sosyal Bilimler Enstitüsü, Ankara.

\section{EXTENDED ABSTRACT}

Communication is important for people to survive. As a social being, human beings feel the need to be together with other people and share their feelings and thoughts. However, when people are communicating, they may feel fears such as not being accepted by others, negatively evaluated and excluded. This situation negatively affects the communication of people. Individuals with this fear do not enter crowded environments, isolate themselves and do not stand out with other people.

According to the study of Wells et al. (1995), individuals who are afraid of being evaluated negatively experience problems not only mentally but also physically and behaviorally because they cannot see that their fears are unfounded. For example, in addition to talking less and staying silent in the community, reactions such as holding the glass tightly, shaking hands and sweating are observed in the individual. However, developments in the new media have started to facilitate the communication of individuals who fear being evaluated negatively. In other words, individuals who are afraid of being evaluated negatively can communicate through social media that they cannot establish in society. The reason for this is that individuals feel more comfortable on social media than face-to-face communication. Because individuals think that they are less threatened because social media provides privacy. This situation causes an increase in social media usage, duration and frequency of visits. According to Çakmak's (2014) research, social media use reduces communication anxiety in individuals. In addition, according to the study conducted by the Prosecutor and Aysan (2018), there is a significant relationship between the fear of being evaluated negatively and the social media addiction of individuals. In this context, it can be said that individuals who fear being evaluated negatively frequently use social media. In this case, it is thought that individuals who fear being evaluated negatively are frequently exposed to social media advertisements. For this reason, the study aims to evaluate the relationship between the attitudes of individuals who fear negative evaluation towards social media advertisements. In addition, whether there is a meaningful relationship between the fear of being negatively evaluated and the reason for preferring social media ads, which are the sub- 
dimensions of the attitude towards social media ads, and consumer opinion, is among the issues being examined. In addition to these, it was also examined whether there is a significant difference between the fear of being evaluated negatively and the demographic characteristics of the consumers. As a result of the data obtained, it is seen that there is a significant difference between the fear of negative evaluation and demographic characteristics of the participants. With the fear of negative evaluation of the participants in the study; It was determined that there is a significant difference between gender, employment, monthly income and daily internet status. In line with the data obtained, it can be said that the men participating in the study are more afraid of being evaluated negatively than the female participants. In addition, it is seen in the study that the participants who are active in business life have less fear of being evaluated negatively than passive ones. In this context, it can be said that the working participants fear being evaluated less. This situation is also seen in the income situation. It is observed that participants with high income levels have less fear of being evaluated than those with low income. In addition to research it was also examined whether there is a meaningful relationship between the fear of negative evaluation and the general attitude towards social media advertisements. In this context, a correlation analysis was made between "fear of negative evaluation", "opinion towards social media ads", "reasons for preferring social media ads" and "general attitude towards social media ads". In line with the data obtained no significant relationship was found between the fear of negative evaluation of the participants and the reasons for preferring social media ads. In addition, according to the research, it is seen that there is no significant relationship between the fear of being evaluated negatively and the reasons for choosing social media ads, which are the subdimensions of the attitude towards social media ads. In addition to these, there is no significant relationship between fear of being evaluated negatively and consumer opinion towards social media ads, which is the sub-dimension of the attitude towards social media ads. In the light of this information, it was concluded that there is no relationship between the attitudes of individuals who fear negative evaluation towards social media advertisements. In the study, only the attitudes of individuals who fear being evaluated negatively towards social media ads were examined. However, in future studies, the purchasing behavior of individuals who fear being evaluated negatively can also be examined. In this context, it is believed that the study will be a guide for future studies. In addition, it is thought that the study will guide the brands in determining their strategies regarding social media advertisements by looking at whether their target audience is afraid of being evaluated negatively. 